\title{
The Effects of Globalization on U.S. Monetary Policy
}

\author{
Augustin Mbemba \\ Correspondence: Augustin Mbemba, Robins School of Business, University of Richmond, VA 23173. Tel: \\ 1-804-287-1815. E-mail: ambemba@richmond.edu
}

Received: April 13, 2012

Accepted: May 9, 2012

Published: June 1, 2012

doi:10.5539/ijef.v4n6p187

URL: http://dx.doi.org/10.5539/ijef.v4n6p187

\begin{abstract}
This paper analyzes the linkages between the effects of globalization on U.S monetary policy. It states that the effects of globalization on monetary policy may be perceived through its impact on the financial and economic environment in which it is implemented. Thus, international phenomena have significant influences on the domestic economy and on the ability to achieve domestic goals. This topic is empirically of particular interest at least for three main reasons: First, the current economic and financial crisis affects the World's economy. Second, world financial markets are currently experiencing substantial turbulence starting with the "subprime" mortgage crisis in the United States and its prominent propagating role through international financial linkages in all the continents. We will review some problems that international considerations are creating for the U.S. economy over the coming decades, such as the more globally connected a country is, the less flexibility it has with its monetary policy. Third, an alternative to using monetary policy to guide the economy toward meeting its international goals is trade policy designed to affect the level of exports and imports and the inflation rate. Finally, we conclude our study by exploring how to restore international trade balance to the U.S. Economy. So as long as other countries are willing to accept U.S. assets in payment for the goods they produce, the United States will continue to run a trade deficit at the current exchange rate.
\end{abstract}

Keywords: globalization, monetary policy, inflation, exchange rates, financial markets

JEL Classification: E43, E44, E50, F40

\section{Introduction}

The twenty-first century saw major changes in the international linkages among countries. National economies are moving toward a single economy and have direct impact on the U.S. economy. Therefore US monetary and fiscal policies have substantial effects on foreign economies and vice versa. The U.S. economy may move toward a growth or recession, consequences will spread over all the continents. Several decades of globalization have impacted the structure of the U.S. economy through changes in patterns of production, employment, trade, and financial flows and global economy. For example, in 1997, Asian countries were forced to devaluate their currencies after banks shut down and unemployment soared. On the Hong Kong market the Heng Seng index dropped nearly a quarter of its value in a 4-day period in October. For months fears rose for worldwide economic depression but fortunately, the crisis did not spread to the rest of the world. Our focus is on important linkages between countries whatever the exchange rate regime. If the United States tightens monetary policy, its interest rates rise and attract capital flow from foreign countries. The dollar appreciates and foreign currencies depreciate. The U.S. appreciation implies a loss in competitiveness because the World demand shifts from U.S. goods to foreign goods particularly from other competitors. As they become more competitive, their output and employment expand. "Financial openness" that we define as the sum of the stocks of external assets and liabilities of foreign direct investment (FDI) and portfolio investment as a percent of GDP, occurred in both industrial and emerging market economies in the second half of the 1990s (Lane and Milesi-Feretti, 2003). Why did these increases in capital movements occur? Capital movements and financial innovations have decreased the cost of holding foreign assets and consequently increased investors' demand for internationally diversified portfolios and the sophisticated vehicles for hedging foreign risk exposure which has reduced the riskiness of a given level of foreign exposure. In the United States, one direct effect of globalization on Federal Reserve operations investigated in this paper has been to increase the time and the attention that policymakers devote to design and to understand the developments in the world trading system and in World Capital.

\section{Literature Review and Methodology of the Effects of Exchange Rates}

From academic perspective, I may distinguish two main developments of modern monetary theory: First, the microeconomic-based theories of wage/price formation into classical monetary models, and, second, the use of 
optimal monetary policy rules to describe and analyze policy. The origins of these developments can be found in the 1970s, but were just fully realized during these last years. Modern monetary theory emphasizes on policy rules for the setting of the interest rate by the central bank. Empirical model statistically estimated and used by Woodford (2003) helped Central banks or interests rates setters. Despite the fact he provided a treatise on the theory of monetary policy specifying that it is all about monetary policy rules, his analysis did not focus on international models or policy issues comparing to Richard Fisher (2006) who presented in his research a relevant case based on the impact of monetary policy on globalization. Strong international aspect of monetary policy was developed by (Taylor (1993)), the Fed, the IMF and Brookings Institutions with the models developed by Levin, Wieland, and Williams (1999)). When the Federal Reserve Bank sets the interest rate, it makes a decision based on the domestic and global current economic conditions within the overall framework of a monetary policy rule. The best canonical example is the Taylor rule, discovered by John B. Taylor (Note 1) of Stanford University (and later undersecretary of the Treasury). Taylor's rule tells the monetary authorities how to set interest rates in response to economic conditions. A general format for a monetary rule is:

$$
i t=r^{*}+\pi t+\propto(\pi t-\pi *)+\beta\left(100 \mathrm{X} \frac{\left(\begin{array}{c}
Y t-Y_{t} * \\
Y *
\end{array}\right)}{t}\right)
$$

$i$ is the prescribed value of the policy interest rate in a given period t. $\mathrm{r}^{*}$ is the « natural » rate of interest or the real interest rate we would see if the economy were at the natural rate of unemployment corresponding to potential GDP $Y_{\mathrm{t}}{ }^{*}$ or $\pi *$ is the Fed's target inflation rate. If $\alpha$ and $\beta$ are large, then the monetary policy rule aggressively respond to excess inflation and to economic booms.

In this case, the Federal Reserve will respond much more aggressively than it will respond to the level of economic activity. For example, to hit a 2 percent inflation target at full employment, the Fed would set the nominal interest rate to be 4 percent. If inflation rate is set at 5 percent with a 2 percent inflation while GDP is 1 percent above potential, Taylor's rule would tell the Fed to set the nominal interest rate at 9 percent $(2+5+0.5 \times[5-2]+0.5$ $\times 1$ ). Even though the monetary policy rule is very helpful as guidelines for monetary authorities, it is not exactly what they do in decisions making process or it does not represent a complete policy analysis. This approach may have some limitations like many rules. We may disagree about the details of this rule but we have to keep in mind many factors are absent from this rule and may be in the same time relevant for monetary decisions.

Theoretically, exchange rate changes induced by monetary policy shocks in one country would be more likely to elicit monetary policy responses in another country. Mishkin (2007) argues that greater openness to trade should boost the role of the exchange rate as a transmission channel of monetary policy. The larger the share of imports and exports in the economy, the greater the change in net exports--and, hence, in the contribution of net exports to gross domestic product (GDP) growth--for a given change in the exchange rate. In addition, the larger the share of imports in the economy, the larger should be the effect on overall CPI inflation of a given change in import prices when the exchange rate changes. Erceg, Gust, and Lopez-Salido (2010) use a number of calibrated New Keynesian models to analyze the effect of shocks in open economies, and they confirm Mishkin's central hypothesis that economic openness increases the role of the exchange rate and net exports in the monetary transmission process while reducing that of exclusively domestic transmission factors. Cwik, Muller, and Wolters (2008) calibrate a New Keynesian DSGE model to match the performance of the U.S. economy as captured in an estimated VAR model. They also find that, all else equal, greater openness to trade would increase the effect of exchange rate changes on macroeconomic performance. However, Cwik, Muller, and Wolters (2008) show that this effect is attenuated if the pass-through of changes in exchange rates into changes in import prices is limited--the more limited the pass-through, the less that prices of imports in domestic currency respond to exchange rates, and thus the smaller the changes in quantities of exports and imports. Gust and Sheets (2007) also use an open-economy DSGE model to make this finding.

As considerable research points of exchange rate in many countries in recent decades--see, among others, Marazzi, Sheets, and Vigfusson, 2005, Campa and Goldberg, 2005, and Ihrig, Marazzi, and Rothenberg, 2006)-- suggest that even as trade globalization may have been bolstering the exchange rate channel of monetary policy transmission, the decline in exchange rate passthrough may have been acting to reduce it (Mishkin, 2007). Consistent with this, di Mauro, Ruffer, and Burda (2008), in their VAR analysis of the euro area, find a decline in exchange rate pass-through to imports and consumer prices, as well as some evidence that trade (especially in goods) has become less responsive to exchange rates. In fact, Gust, Leduc, and Vigfusson (2006) develop a theoretical model to argue that the simultaneous occurrence of increases in trade openness and declines in pass-through may be no coincidence: increases in trade introduce more foreign competitors into the domestic market, leading to more variable markups over cost and less pass-through of exchange-rate changes into import prices. 
Finally, another channel through which globalization might affect the exchange rate channel of monetary transmission might be valuation effects associated with cross-border assets and liabilities. Presumably, as these positions have grown, the valuation and wealth effects associated with exchange rate changes should have grown as well (Lane and Milesi-Ferretti, 2005, Tille, 2008). In practice, however, it is difficult to identify this evolution.

\section{The Implications of Globalization on Exchange Rates}

Basically, the exchange rate plays three significant roles in international monetary theory. First, its expected change affects relative rates of return from holding dollars versus other major currencies such as Euro, British pounds or yen as capital can move instantaneously in international financial markets to obtain the best return. Second, its level obviously affects the relative price of goods and labor in different countries, affecting exports and imports. And, third, its past and expected rate of change affects inflation through the pass-through mechanism. Despite the fact that globalization puts long-term interest rates under global factors, in a floating exchange rates regimes such as the United States economy, Federal Reserve Bank retain the ability to control short-term interest rates. Formally or informally targeting inflation and other elements, monetary policies in many economies have become more similar in their response to external shocks. In the reality, there is little support for the assertion that financial globalization has increased the responsiveness of exchange rates for major developed economies.

In the meantime, The United States operates in a global economy and that policy today must consider global issues. Global issues restrict the use of monetary and fiscal policy to achieve domestic goals. How fast a country must respond to international pressure depends on the exchange rate regime it follows. If an economy sets fixed exchanges rates, its monetary policy is much more restricted than it is with flexibility exchange rates. The main reason is that the amount of currency stabilization that may be realized with direct intervention is generally small since a country's foreign reserves are limited. If it happens, a country must adjust the economy to the exchange rate to keep its currency fixed by either changing the private supply and demand of its currency, using monetary policy. It means that if monetary policy is being used to achieve exchange rate goals, it cannot be domestically used to achieve domestic goals. If a country uses flexible exchange rates, it has more freedom with its monetary policy, but it must accept whatever happens to its exchange rate, and there are often political forces that do not want to do that. This is the position in which the United States will find itself if foreigners significantly reduce their demand for U.S. assets.

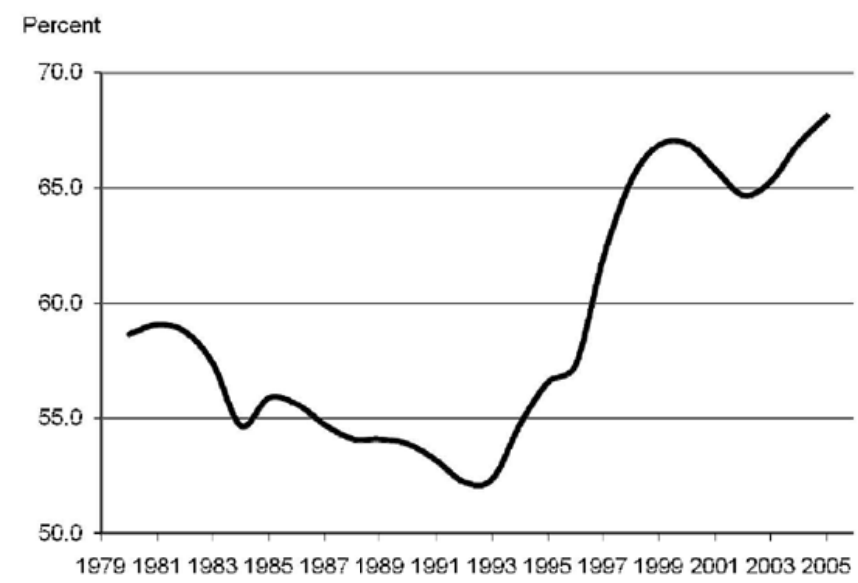

Figure 1. Assets of Globally-Oriented U.S. Banks as a Share of Total U.S. Bank Assets (1980-2006)

Source: Cetorelli and Goldberg (2009)

Whenever market participants buy something that has been made abroad, a car, a stock or a bond, someone somewhere has exchanged dollars for the currency used where the item was made. The exchange rate plays three basic roles in global economy. First of all, the expected exchange rate of the change of the exchange rate affects the return from holding one currency compared to another. A depreciation of US dollars may follow our decision of cutting the interest rate in the United States. The second role played by the exchange rate can be viewed as an impact on exports and imports where a trade deficit will lead to a depreciation of the currency. The last role emphasizes on the percentage change in the exchange rate that affects inflation. As result, the exchange rates have 
broad implication for individuals and for countries. As evidenced by a review of the recent history of exchange rates in the midst of economic and financial turmoil in South Korea in 1997/1998 where output and employment plunged. Due to the fact that large industrial and financial industries approached bankruptcy, the number of South Korean won needed to purchase one dollar more than doubled rising from 900 to 1,900. The consequences were dramatic inside South Korea but also in other countries. In 1973, the British pound was worth $\$ 2.50$. Over the 36 years, its value declined by $35 \%$ reaching $\$ 1.62$. In the meantime, Americans visiting London during summer 2009 found out that they paid more on their purchases as a low-price hotel room in London cost about the same as fairly expensive room in New York. Another example is related to what happened in 2000 in global financial exchange rates markets.

To understand domestic impact from global exchange rates market, let review recent historical evidence. In 2000, the Federal Reserve Bank of New York's foreign exchange rates Office bought Euros for the first time after the new currency was adopted by European countries. Meanwhile, central bank officials in London, Tokyo, Frankfurt, and Ottawa (Canada) did the same by buying between $€ 4$ and $€ 6$ billion. The Fed alone bought $€ 1.5$ billion for $\$ 1.34$ billion. At the end of this operation the ECB press released the information that they did it because of "shared concern about the potential implications of recent movements in the euro exchange rate for the world economy." Since its introduction on January 1, 1999, the euro had fallen steadily from $\$ 1.18$ to $\$ 0.85$, a decline of more than 25 percent. Though its low value had made exports cheap, bolstering the foreign sales of European-made products, it had also forced up the prices of imports. European Central Bank (ECB) officials, charged with maintaining price stability, found the high price of imports because they really did not want to raise interest rates just to bolster the value of their currency. The coordinated intervention in the foreign exchange market made headlines worldwide. In the same way, Argentina is an interesting case of how external and domestic factors interact in the making of monetary policy. For many years, Argentina has suffered from severe inflation averaging 100 percent during 1970s while the economy grew about 3 percent. By 1989, inflation had climbed to more than 2,000 percent per year and the price level was 60 billion times what it had been 20 years before. To discipline policymakers, in 1991 Argentineans implemented a mechanism called a currency board, which had two important factors.

First, Argentina's central bank, the Banco Central of Republica of Argentina, guaranteed that it would exchange Argentinean pesos for U.S. dollars on a one-for-one basis; it fixed its exchange rate. Second the central bank was required to hold dollar assets equal to its domestic currency liabilities, again one-to-one exchange rate. For every peso note that was issued and every peso in commercial bank reserves that it created, the Central Bank of Argentina had to hold one U.S. dollar. These two examples of the European Central Bank and Argentina suggest a relationship between domestic monetary policy and exchange rate policy. To control the inflationary impact of fiscal and monetary policies, Argentina fixed its exchange rate to the dollar. To avoid raising domestic interest rates, the ECB organized a coordinated intervention to shore up the value of euro. Despite the importance of its historical role, economic theory and empirical model show that the change in exchange rates have less significant impact on monetary policy. In my prospective research I expect to look at several factors that determine the inflation rate. International factors may also affect inflation in the United States. Today, markets participants as households, governments, business firms are more concerned about financial conditions around the World. For example, financial markets are influenced by the unrest in Middle East in Africa and other sudden changes or climatic changes in the World. Shocks to food and oil prices caused by extreme weather conditions cause inflation to fluctuate in short run. We may be tempted by concluding that these financial conditions and changes limit the influence of the US monetary policy and directly, the role of Federal Reserve in long run. How all of this affect monetary policy?

\section{What Are the Implications of Globalized Financial Markets for Domestic Monetary Policy?}

As markets are globalized, the financial environment in which U.S. monetary policy operates is constantly changing due to the importance of financial flows into and out of the United States. Comparing to many years ago when U.S. financial assets were just held by some foreign investors and institutions, today foreign and domestic investors are internationally diversified. For instance, one-quarter of the long-term fixed-income securities issued by U.S. institutions is held by foreigners. In 2006, foreigners acquired on net more than $\$ 1.6$ trillion in U.S. assets, while U.S. investors purchased more than $\$ 1$ trillion in foreign assets. Consequently, capital inflows and outflows certainly influence long-term U.S. interest rates and affect the supply and demand of capital investment and saving. 


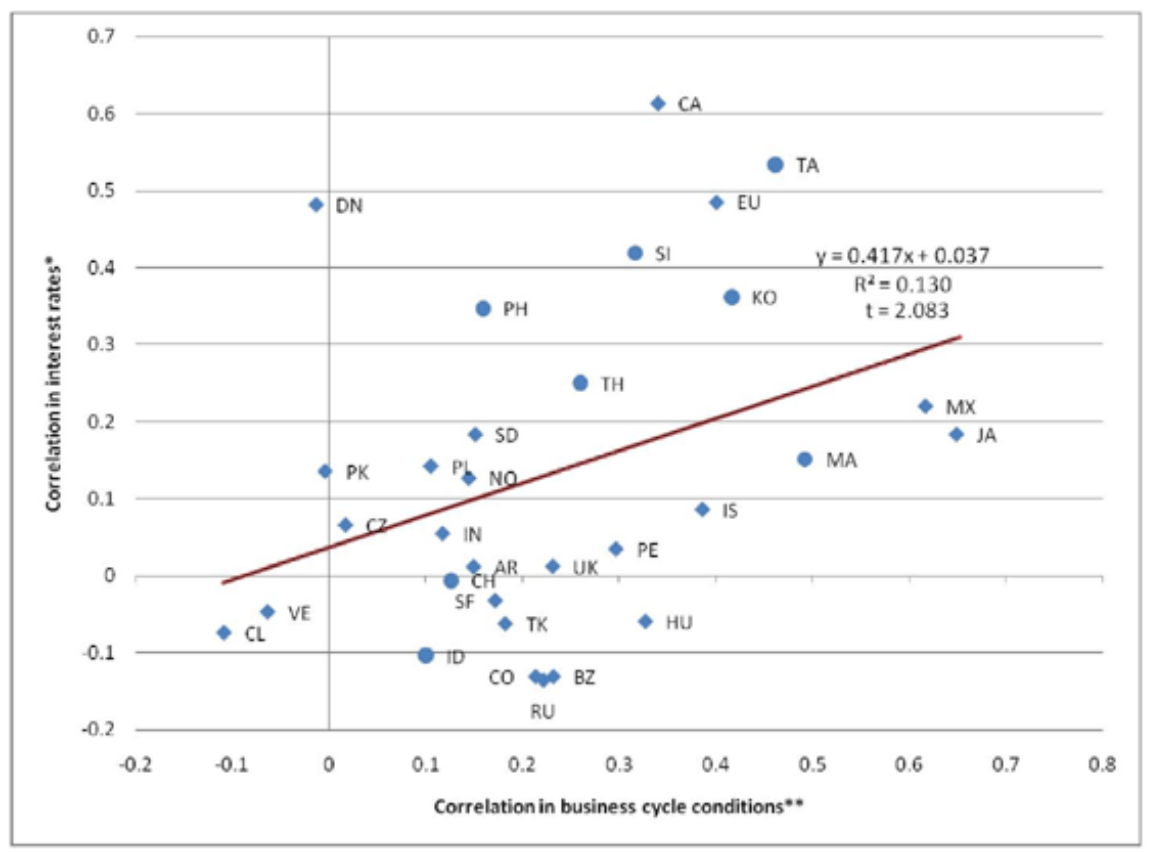

Figure 2. Correlations of Nominal Interest Rates with U.S. vs. Correlations of Business Cycle Conditions with U.S. (January 2000 - December 2007)

Source: Federal Reserve Bank, 2007

The first stages of the monetary policy transmission for monetary policy as summarized in table 1 show that using open-market tools, the Federal Reserve handles money supply in the interbank system. These open-market purchases and sales have also an impact on the Fed's balance sheet. In the meantime, the federal funds rate does not have a straight impact on economic activity but the Federal Reserve's ability to control the federal funds rate gives it a strong influence over other short-term dollar nominal interest rates. If the Fed can set the short term interest rate is because of the nature the dollar. The dollar is a freely floating currency.

Differences in financial structures across nations will determine the effectiveness of monetary policy used by central banks. As markets become global, markets participant's households and business firm face more competition. The U.S. and other countries' economies and globalization led to the complexity of implementing an effective monetary policy and increase Federal Reserve Bank and other central banks responsibility to stabilize prices and output. The implications of global markets on monetary policy are explained by the study of the first steps of the monetary policy transmission mechanism such as federal funds rate, the interest rate at which banks lend to each other or the use of open-market operations and other tools. Another aspect is that global financial markets increase financial interdependence among nations. Correlations can be found between long term interest rates in the United States and other industrial countries for instance German, Canada, the United Kingdom... 
Table 1. The Monetary Policy Transmission

\begin{tabular}{ll}
\hline \multicolumn{1}{c}{ Channel } & \multicolumn{1}{c}{ Mechanism } \\
\hline Interest rates (traditional channel) & $\begin{array}{l}\text { Lower interest rates reduce the cost of investment, making } \\
\text { more projects profitable. }\end{array}$ \\
Exchange rates (traditional channel) & $\begin{array}{l}\text { Lower interest rates reduce the attractiveness of domestic } \\
\text { investment, depressing the value of the currency and } \\
\text { increasing net exports. }\end{array}$ \\
Bank lending & $\begin{array}{l}\text { An easing of monetary policy raises the level of bank reserves } \\
\text { and bank deposits, increasing the supply of funds }\end{array}$ \\
Firm's balance sheets & $\begin{array}{l}\text { Lower interest rates raise firms 'profits, increasing their net } \\
\text { worth and reducing the problems of adverse selection and } \\
\text { moral hazard. }\end{array}$ \\
Household net worth & $\begin{array}{l}\text { Lower interest rates raise individual's net worth, improving } \\
\text { creditworthiness and allowing them to increase their } \\
\text { borrowing. }\end{array}$ \\
Asset prices & $\begin{array}{l}\text { Higher stock prices and real estate values fuel an increase in } \\
\text { both business and household consumption. }\end{array}$ \\
\hline
\end{tabular}

Even though financial markets has not reduced the ability of the Federal Reserve to affect financial conditions in the United States, but Federal Reserve Bank has to pay a close attention on that interdependence conditions abroad and in the U.S. including some empirical research which support the view that U.S. monetary policy retains its ability to influence longer-term rates and other asset prices.

\section{How Do International Factors Domestically Influence The Determination of U.S Inflation Process?}

The Federal Reserve has changed the way in which monetary policy is implemented over many years. In the late 1970s and early 1980s, it set a target level for the money supply and altered the monetary base to achieve that target. In this method the Federal Reserve acted freely through federal funds fluctuations. Today, The Federal Reserve uses the reverse procedure such as setting a target for the federal funds rate and allowing the money supply to fluctuate. A common mistake is to consider that these changes in the Federal Reserve's rules alter the way the money market work. In fact, the money market works the say way as always: the interest rate for example is determined by the supply and the demand for money. It is not set by the Federal Reserve as many argue. The only difference is that the Federal Reserve adjusts the supply of money to achieve its target interest rate. Therefore it is critical to not confuse a change in the Fed's operating procedure as explained in table 2 with a change in the way the economy works. 
Table 2. Expansionary monetary policy

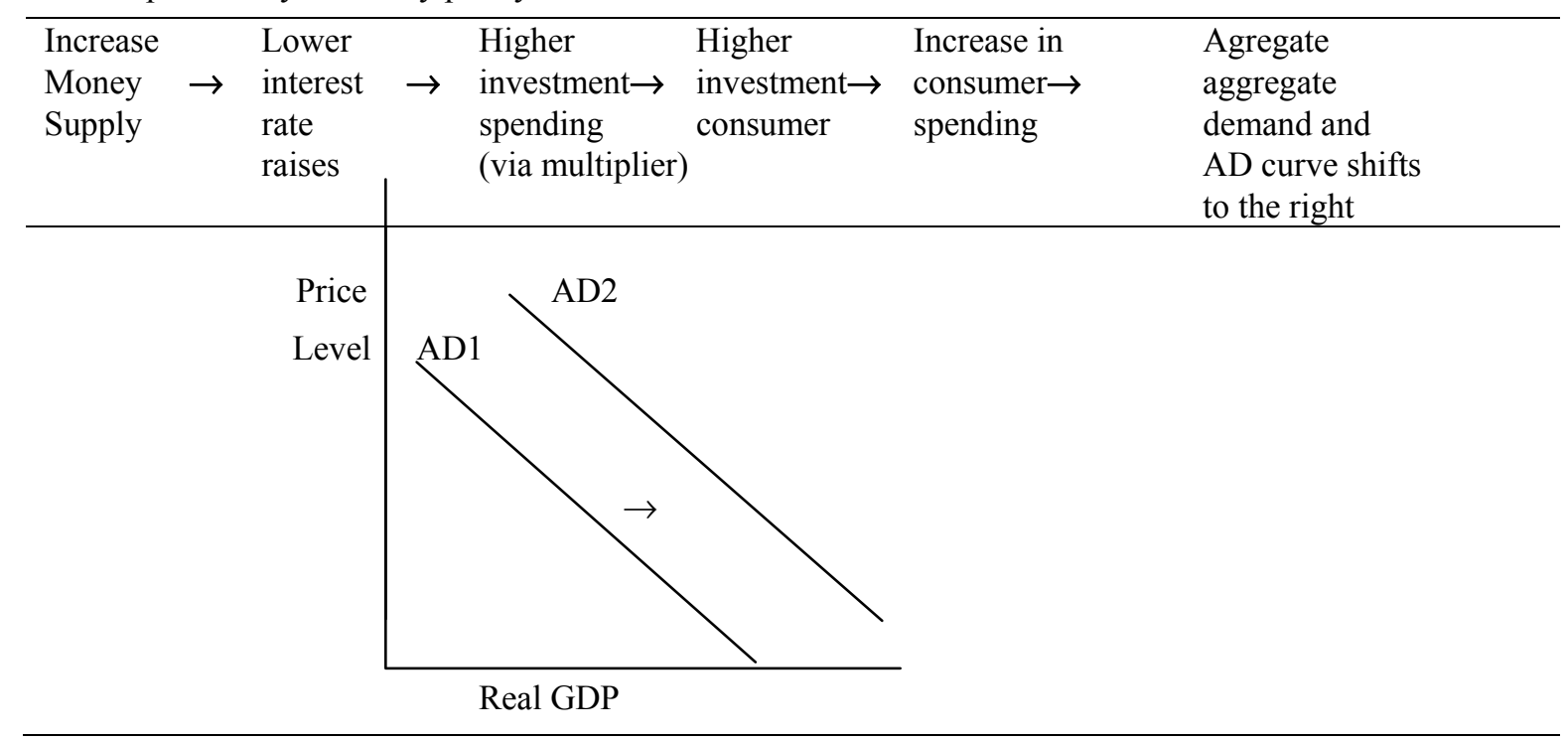

Table 2 shows the adoption of expansionary monetary policy by the Fed, and an increase of monetary supply. Interest rates fall leading to higher investment spending, which raises income, which, in turn, raises consumer spending shifts the $\mathrm{AD}$ curve to the right.

Table 3. Contractionary monetary policy

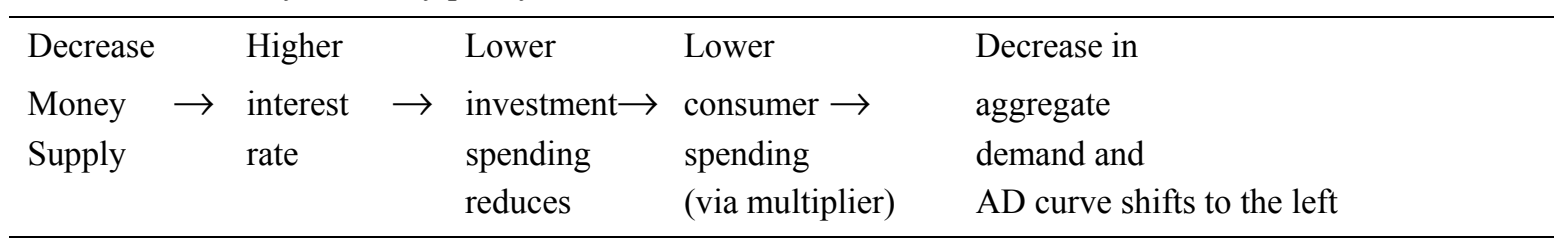

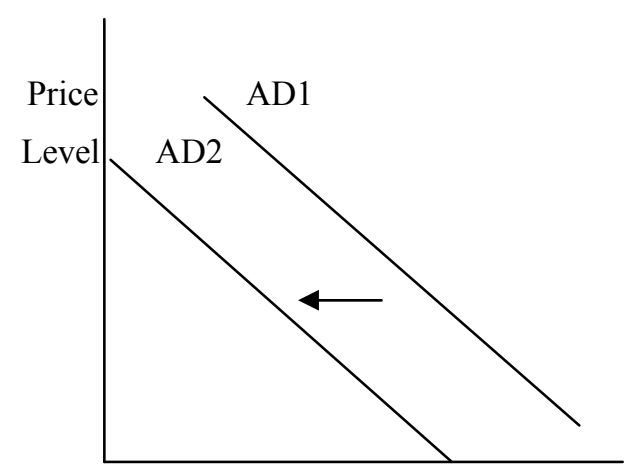

Real GDP

Table 3 shows the adoption of contractionary monetary policy by the Fed, and a decrease of monetary supply. Interest rates rise, leading to lower investment spending and a reduction in income. This lowers consumer spending and a reduction in income. This lowers consumer spending and shifts the AD curve to the left.

Currently, monetary policy is quite similar among developed nations. Each major nation has a central bank including the Eurozone. All the central banks want to keep the aggregate price level roughly stable or around $2 \%$ or $3 \%$ per year. As we stated above, if we look at the label of a shirt, chances are it was imported from China, India, or somewhere else in Asia. The reason is that it is less costly to manufacture clothing in places where labor is inexpensive. Consequently, clothes are cheaper in the Unites States: trade lowers prices, but if trade lowers prices in the U.S, does it lower inflation? 
The simplest way to understand the effects of international trade on the U.S. inflation rate is to analyze it as a source of productivity enhancing technological progress. Shifting production clothes from domestic factories to foreign ones is the same as U.S. producers finding a new, cheaper technology for producing the same things at home. And improvements in technology increase potential output. An increase in potential output shifts both the long-run and short-run aggregate supply curves to the right.

The immediate impact of shifting the economy along its dynamic aggregate demand curve to a point where output is higher and inflation is lower. Thus, globalization and trade do reduce inflation in the short run and just like any positive supply shock they provide an opportunity to reduce inflation permanently. In 1990s, Federal Reserve policymakers took advantage of an increase in potential output to drive the U.S.inflation rate down from 5 percent at the end of the 1990-91 recession to $1 \frac{1 / 2}{2}$ in 1998. This drop in inflation occurred during an economic boom. Over the last half of the 1990s economic growth averaged 11/2 percentage points above the rate for the preceding 20 years. That is, U.S. productivity (and potential output) grew more rapidly from 1996 to 1999 than it did from 1975 to 1995. In effect, the Federal Reserve took the opportunity to reduce their implicit inflation target from near 5 percent to below 2 percent (disinflation). During the 1990s, Fed policymakers exploited the opportunity afforded them by positive supply shocks to permanently lower inflation. Globalization cause inflation to depend on the prices of imported goods because of the competition between domestic products and products made abroad. The pricing power of suppliers or business firms are affected and consequently, the productivity growth. As markets become global and integrated markets participants who supply goods, services and labor may face more competition because prices and wages can be determined by both local and foreign markets. Open- economies are interdependent and gain from trade.

With the development of high technology and internet, it is easier to order and to use goods and services made overseas. In individual perspective, from drinking a juice made from oranges grown in Florida, hot chocolate from beans grown in Ivory Coast, watching a news broadcast from Los Angeles on a television made in Japan to wearing clothes made in China and driving a car made of parts manufactured in several countries around the world, we all are active participants of international trade system. In global business perspective, transactions are not only limited to goods and services, but also involve investing such as buying and selling bonds, stocks in global financial markets. Obviously in short run, international trade and globalization affect domestic inflation and just like any positive supply shocks they provide an opportunity to reduce inflation permanently. While a better understanding of implications of globalization will help us to understand inflation dynamics, it is clear that international factors may have an impact on domestic inflation through several channels: prices of imported goods, productivity growth, pressures on resource utilization in foreign countries. Those factors will be explored in my research as research associate.

\subsection{The Impact of Imported Goods}

An important part of any of us spends on imported goods pays for the costs of domestic transportation and the retail store where we shop. The amount of this domestic content of imported goods varies substantially with toys and clothing having as much as 90 percent and automobiles as little as 10 percent. Another point is that an alternative to using monetary policy to guide the economy toward meetings its international goals is trade policy designed to affect the level of exports and imports. Specific use of tariffs and quotas is limited by international conventions, but indirect policies to affect imports and exports are often implemented. For example, U.S. tax laws can be designed to make it more costly for companies to produce abroad. Implicit subsidies can be given for exports and implicit constraints can be placed on imports. We can expect such programs to continue and to expand in the coming decade as the United States attempts to reduce its trade deficit by means other than a fall in the exchange rate of the dollar, which is the alternative path to reducing its trade deficit.

Empirical research shows that international transactions or trade with developing countries decreased the rate of growth of import prices from 1/2 to 2 percentage points in developed countries. Between 1993 and 2002, trade with China reduced annual import price inflation in The United States by 1percentage point (Kamin, Marazzi, and Schlinder, 2006) (Note 2). Another research form the International Monetary Funds shows that the prices of domestic products were restrained by competition from imports (IMF, 2006). When Ben S. Bernanke was sworn in as the $14^{\text {th }}$ chairman of the Board of Governors of the Federal Reserve System, he said: "Our mission, as set forth by the Congress, is a critical one: to preserve price stability, to foster maximum sustainable growth in output and employment, and to promote a stable and efficient financial system that serves all Americans well and fairly." (Note 3) Greater openness to trade increases the influence of imports prices on domestic inflation. The greater openness of the U.S. economy and the impact of global economies leave the United States more open to international influences. In one hand, a more open economy can be more forgiving as excesses in demand are absorbed by other countries through adjustments of our imports and exports. Thus the United States may draw up world capacity; the 
inflationary effect of an increase in aggregate demand might be damped for a time. By early 2010, the Fed had presented the public with considerable detail about the tools that it would use-"at the appropriate time"- to tighten monetary policy and exit from the unconventional policies that it had implemented during the financial crisis of 2007-2009. The large size and unusual composition of the Fed's post-crisis balance sheet meant that the procedures for tightening would be different than in normal periods. By raising interest rate that it pays on reserves, the Fed is able to tighten policy without shrinking its balance sheet. When the Fed tightens see if you can detect the shift by examining its assets and liabilities, which are reported each week in Federal Reserve Statistical Release. The United States is also subject to inflationary forces from other countries including those that might accompany a shift to a more sustainable pattern of global spending and production. In the global economy with separate currencies that can fluctuate against each other over time, each country central bank determines its inflation rate. If the FOMC allows the U.S. economy to run beyond its sustainable potential, inflation would rise. If the influence of globalization on inflation is as substantial as many claim, we might have expected the standard model to have had difficulty in predicting recent inflation trends. For instance, if recent increases in world labor supply are restraining domestic unit labor costs to a significant degree, or if there are other important influences on inflation that are related to globalization but difficult to quantify in the context of the standard model, we would expect to have seen sizable model errors over the past several years. An empirical research used out-of-sample dynamic simulations of a model for core PCE price inflation estimated from 1985 through the end of 2001, we find that although the model over predicts inflation over the past several years, the errors average only 0.1 to 0.2 of a percentage point per year. What do I claim from all this evidence is that the greater integration of U.S. economy into a rapidly evolving world economy has affected the dynamics of inflation determination.

\subsection{How to Restore International Trade Balance to the U.S. Economy?}

The theory of comparative advantage provides the long-run setting within which short-run policy is conducted. As long as other countries are willing and able to accept U.S. currency or U.S. assets in payment for the goods that they produce, the United States may continue to run a trade deficit at the current exchange rate. At some point, foreigners will stop to accumulate more U.S.currency or assets. When this happens, under the assumption of nothing else changes, the dollar will depreciate until the United States regains comparative advantage in enough goods and services to create a balance of payments without inflow of foreign financial assets. This point leads our discussion to the competitiveness of the ability of a country to sell its goods to other countries. This suggests that globalization pressures on U.S. macro policy will keep U.S. growth slower than what it otherwise would be, and place continual downward pressure on US wages for workers producing an expanding number of tradable goods. Also, differences in financial structure across countries may help explain differences in the effectiveness of monetary policy. Consequently, changes in the structure of financial system will affect monetary policy. One of the primary channels through which monetary policy influences real output and inflation is its impact on the supply of bank loans. By influencing bank lending, policy makers can affect the ease with which individuals and business firms obtain financing.

\section{Conclusion}

Globalization has not empirically affected the ability of the Federal Reserve Bank to influence financial environment in the United States neither preventing monetary policymakers to achieve their goals, but they have to consider a diverse set of global influences because globalization complicates monetary policy for two main reasons: inflation as one of the key macroeconomic topic is increasingly subject to international forces. It means that coordinated global policy between central banks is critical to all the economies such as with the European Union.

Second, Globalization complicates the impact of monetary policy on long-term rates. The Fed faces a challenge by changing short term rates because it has a strong influence on the long term rates such as Mortgages and commercial loans. Over the past several decades, interest rates across the global economy have come to move ever more closely with each other. Prior empirical research has not been able to conclusively tie these increased co-movements to increased financial market integration, as other trends appear to be complicating the analysis, most notably a tighter anchoring of inflation expectations that appears to be diminishing the response of yields to all sorts of shocks, domestic and external. However, taking all of the evidence and prior research into consideration, our judgment is that the trend toward heightened correlations in interest rates across countries very likely reflects financial globalization, particularly as there is little evidence that business cycles have become more internationally synchronized.Even so, globalization appears to be amplifying the role of international considerations in the formation of domestic monetary policy. First, it is clear that even with floating rates, the short-term rates set by monetary policymakers in many economies are responding to foreign financial conditions, and apparently to a greater extent than previously. This could be because globalization is rendering exchange rates more sensitive to interest rate differentials, and even central banks with floating currencies will need to respond to changes in 
exchange rates. It could also be because exchange rates are becoming a more important channel of monetary transmission. A final explanation for the increased co-movement in short rates observed across economies is that monetary policy strategies around the world are becoming more similar with the adoption of inflation targeting and other elements of good practice in central banking.

In addition to short rates, long-term interest rates appear increasingly to be affected by international developments as well. This poses a challenge to central bank policymakers, who must not only understand the implications of, and formulate a response to, domestic shocks, but must also take into account a diverse array of external shocks. In a speech a few years ago, Federal Reserve Board Chairman Ben Bernanke noted that although globalization has not "materially affected the ability of the Federal Reserve to influence financial conditions in the United States, nor has it led to significant changes in the process that determines the U.S. inflation rate...effective monetary policy making now requires taking into account a diverse set of global influences, many of which are not fully understood" (Bernanke, 2007a).

Finally, the recent crisis has both underscored the challenges of monetary policy in a globalized financial system and highlighted the importance of liquidity and credit channels as additional conduits of external shocks. The crisis has also identified an area in which the standard array of central bank tools may have become inadequate in many countries: liquidity provision and the lender-of-last resort function. With the rise in the share of financial transactions undertaken in vehicle currencies such as dollars and Euros, the ability to print domestic currency may no longer suffice to address a liquidity crisis. Accordingly, international arrangements for liquidity provision may become increasingly important in the future.

\section{References}

Anderson, T. G., Bollerslev, F., X. Diebold, \& C. Vega (2003). Micro Effects of Macro Announcements: Real-Time Price Discovery in Foreign Exchange. American Economic Review, 93(1), 38-62. http://dx.doi.org/10.1257/000282803321455151

Bernanke, Ben S. (2008). Policy Coordination Among Central Banks, At the Fifth European Central Bank Central Banking Conference, The Euro at Ten: Lessons and Challenges, Frankfurt, Germany, November 14.

Bernanke, Ben, \& Kenneth N. Kuttner. (2005). What explains the Stock Market's Reaction to Federal Reserve Policy? Journal of Finance, 60, 1221-1257.

Carlozzi, Nicholas, \& John B. Taylor. (1985). International Capitak Mobility and the Coordination of Monetary Rules. Exchange Rate Management under Uncertainty, Jadeep S. Bhandari (Ed.) 186-211, MIT Press, Cambridge, Massachusetts.

Coenen, Gunter, Giovanni Lombardo, Rank Smets, \& Roland Straub. (2007). International Transmission and Monetary Policy Cooperation, paper presented at the NBER Conference on International Dimensions of Monetary Policy, Girona, Spain.

Di Mauro, Filippo, Rasmus Ruffer, \& Irina Bunda. (2008). The Changing Role of the Exchange Rate in a Globalized Economy. ECB Working Paper Series, No.94, September.

Fisher, Richard. (2006). Coping with Globalization's Impact on Monetary Policy, Remarks at the National Association for Business Economics, Panel Discussion at the 2006 Allied Social Science Associations Meeting, Boston, Massachusetts (January 6)

Frederic S. Mishkin. (2007a). Inflation Dynamics. International Finance, 10(3), 317-334. http://dx.doi.org/10.1111/j.1468-2362.2007.00205.x

Governor Frederic S. Mishkin. (2006b). Globalization: A Force for Good? speech delivered at Baruch College, New York, N.Y., October 12

Governor Frederic S. Mishkin. (2007b). Globalization and Financial Development, speech delivered to the New Perspectives on Financial Development Conference, Washington, D.C., April 26.

International Monetary Fund. (2006). How has Globalization Changes Inflation? World Economic Outlook, Washington, D.C.: IMF, April, pp.97-134.

Lane, Philip R., \& Gian Maria Milesi-Ferretti. (2003). International Financial Integration. IMF Staff Papers, 50, Special Issue, pp.82-113

Mark E. Doms, \& J. Bradford Jensen. (1998). Productivity, Skill, and Wage Effects of Multinational Corporations in the United States, in Foreign Ownership and the Consequences of Direct Investment in the United States: Beyond Us and Them, eds. Douglas Woodward and Douglas Nigh (Wesport, CT: Quorum Books): 49-68. 
Mishkin, Frederic S. (2006a). The Next Great Globalization: How Disadvantage Nations Can Harness Their Financial Systems to Get Rich. Princeton University Press.

Nickell, Stephen. (2005). Why Has Inflation Been So low Since 1999? Bank of England Quarterly Bulletin, 5, 92-107. London.

Roberts, John M. (2006). Monetary Policy and Inflation Dynamics. International Journal of Central Banking, 2, 193-230

Taylor, John B. (1993). Macroeconomic Policy in a World Economy: From Econometric Design to Practical Operation, W.W. Norton, New York

Woodford, Michael. (2003). The Return of Monetary Policy Rules, Chapter 1, Interest and Prices: Foundations of a Theory of Monetary Policy. Princeton University Press, Princeton

Yellen, Janet. (2006). Monetary Policy in a Global Environment, speech delivered at the conference, The Euro and the Dollar in a Globalized Economy, University of California at Santa Cruz, Santa Cruz, California, May 27.

\section{Notes}

Note 1. John B. Taylor, "Discretion versus Policy Rules in Practice," Carnegie-Rochester Conference Series on Public Policv, 1993. For a good discussion, see John P. Judd and Glenn D. Rudebusch, "Taylor's Rule and the Fed: 1970-1997," Federal Reserve Bank of San Francisco Review, 1998.

Note 3. The share of imports coming from China is relatively high for the United States, and so the effect of trade with China may be lower for industrialized countries. For example, one analysis of trade between the United Kingdom and both China and India found that, over the period 1999-2002, the effect on import-price inflation was only about 0.5 percentage point annually (Nickell, 2005). Research by the European Central Bank, however, found that Euro area's trade with a wide range of developing economies had reduced the rate of increase in import prices to the area wide range of developing points annually over 1996-2005 (European Central Bank, 2006).

Note 3. Remarks by Chairman Ben S. Bernanke at the ceremonial swearing-in by President George W. Bush, Federal Reserve Board of Governors, Washington, D.C., February 6, 2006. 